\title{
Petrotectonic framework of granulites from northern part of Chilka Lake area, Eastern Ghats Belt, India: Compressional vis-à-vis transpressional tectonics
}

\author{
Kaushik Das ${ }^{1, *}$, Sankar Bose ${ }^{2, *}$, Subrata Karmakar ${ }^{3}$ and Supriya Chakraborty ${ }^{2}$ \\ ${ }^{1}$ Department of Earth Sciences, Bengal Engineering and Science University, Shibpur, Howrah, India. \\ ${ }^{2}$ Department of Geology, Presidency University, Kolkata, India. \\ ${ }^{3}$ Department of Geological Sciences, Jadavpur University, Kolkata, India. \\ *Corresponding author.e-mail: kaushik.met@gmail.com
}

\begin{abstract}
Granulite-facies rocks occurring north-east of the Chilka Lake anothosite (Balugan Massif) show a complex metamorphic and deformation history. The $\mathrm{M}_{1}-\mathrm{D}_{1}$ stage is identified only through microscopic study by the presence of $S_{1}$ internal foliation shown by the $M_{1}$ assemblage sillimanite-quartz-plagioclasebiotite within garnet porphyroblasts of the aluminous granulites and this fabric is obliterated in outcrop to map-scale by subsequent deformations. $\mathrm{S}_{2}$ fabric was developed at peak metamorphic condition $\left(\mathrm{M}_{2}-\right.$ $\mathrm{D}_{2}$ ) and is shown by gneissic banding present in all lithological units. $\mathrm{S}_{3}$ fabric was developed due to $\mathrm{D}_{3}$ deformation and it is tectonically transposed parallel to $\mathrm{S}_{2}$ regionally except at the hinge zone of the $\mathrm{F}_{3}$ folds. The transposed $\mathrm{S}_{2} / \mathrm{S}_{3}$ fabric is the regional characteristic structure of the area. The $\mathrm{D}_{4}$ event produced open upright $\mathrm{F}_{4}$ folds, but was weak enough to develop any penetrative foliation in the rocks except few spaced cleavages that developed in the quartzite/garnet-sillimanite gneiss. Petrological data suggest that the $\mathrm{M}_{4}-\mathrm{D}_{4}$ stage actually witnessed reactivation of the lower crust by late distinct tectonothermal event. Presence of transposed $\mathrm{S}_{2} / \mathrm{S}_{3}$ fabric within the anorthosite arguably suggests that the pluton was emplaced before or during the $\mathrm{M}_{3}-\mathrm{D}_{3}$ event. Field-based large-scale structural analyses and microfabric analyses of the granulites reveal that this terrain has been evolved through superposed folding events with two broadly perpendicular compression directions without any conclusive evidence for transpressional tectonics as argued by earlier workers. Tectonothermal history of these granulites spanning in Neoproterozoic time period is dominated by compressional tectonics with associated metamorphism at deep crust.
\end{abstract}

\section{Introduction}

Reconstructing structural history of a poly-metamorphosed and poly-deformed high-grade terrain is often a difficult task as imprints of earlier events are seldom preserved during subsequent high-temperature metamorphism. Mineralogical change, partial melting, intensive deformation and recrystallization of the earlier foliation-defining assemblages are collectively responsible for obliterating earlier structures in granulite-grade rocks. This is particularly a problem for high-temperature and ultra-high temperature granulites. Deformation and kinematic analysis of lower crustal rocks is often fraught with uncertainty but successfully adopted in many regional granulite terranes (Goscombe 1992; Kelly et al 2000; Forbes et al 2007; Sarkar et al 2007 among others). Integrated

Keywords. Poly-phase metamorphism; superposed folding; Chilka Lake granulites; Eastern Ghats Belt; oblique collision. 
metamorphic and deformation history with a reasonable support from geochronological data, can be used as a significant tool to understand evolutionary history of orogenic belts (cf. Möller et al 2007). Such orogenic belts of Precambrian era are presently manifested as eroded mountain belts bordering cratons and are key witnesses to everchanging lithospheric processes (Saha et al 2008; Karmakar et al 2009). The history of continental growth and eventual juxtaposition of ancient continents during supercontinent assembly can be traced back from such mountain belts exposed in different continents (Zhao et al 2004; Rogers and Santosh 2002, 2009). Continental growth, either by collisional or by accretional orogeny depends on relative positions of the continental and/or oceanic plates, having distinct magmatic, metamorphic and deformation styles. Understanding the comprehensive history of deformation and metamorphism during orogenesis in Precambrian time is a major challenge.
Eastern Ghats Belt (EGB) of India witnessed multiple cycles of orogeny throughout the Proterozoic eon (Dasgupta and Sengupta 2003; Dobmeier and Raith 2003; Bhadra et al 2004; Sarkar et al 2007). It is now understood that each of these orogenies was connected to global-scale supercontinent cycle. As a consequence, the EGB stands alone as a witness to the formations of Columbia, Rodinia and Gondwana (cf. Karmakar et al 2009; Bose et al 2011a). Chilka Lake area is situated at the northern fringe of EGB close to the Singhbhum Craton. This area exposes rocks of petrological, structural and isotopic characteristics which are quite distinctive compared to the rest of EGB. This distinction led earlier workers to conceive Chilka Lake area as a separate block whose ancestry is poorly known. The deformation history is arguably dominated by transpressional tectonics unlike other parts of EGB (Dobmeier and Simmat 2002). This particular point needs to be reappraised because an entire geodynamic evolution

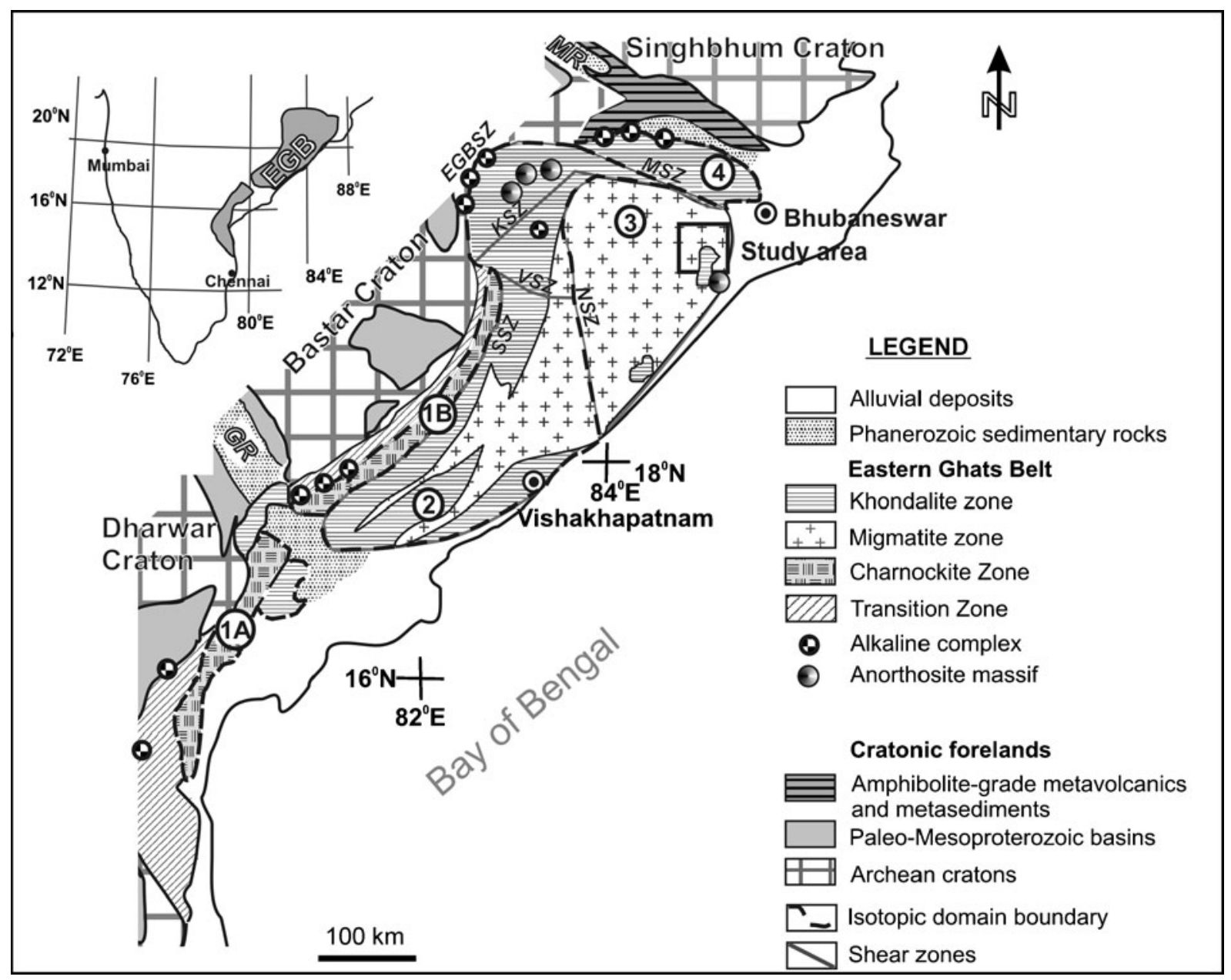

Figure 1. General lithological map showing the Eastern Ghats granulite belt and the present study area. The subdivisions are after Ramakrishnan et al (1998). Isotopic domains (shown as roman numerals within circles) are after Rickers et al (2001). Abbreviations used are MR: Mahanadi Rift, GR: Godavari Rift, SSZ: Sileru Shear Zone, KSZ: Koraput-Sonepur Shear Zone, EGBSZ: Eastern Ghats Boundary Shear Zone, MSZ: Mahanadi Shear Zone, NSZ: Nagavalli Shear Zone, VSZ: Vamasdhara Shear Zone. 
was based on it. A new set of independently acquired field data and its evaluation would be the foremost and simplest proposition to start with.

The present study area is located at the northeastern part of Chilka Lake, EGB, and extends along a linear belt from Khurda to Sunakhala covering approximately $700 \mathrm{~km}^{2}$ area (figure 1). For convenience in presenting structural data and detailed structural analyses, the present study area is divided into two sectors. Sector-1 constitutes the north-eastern part of the study area within the latitude $20^{\circ} 00^{\prime}-20^{\circ} 15^{\prime} \mathrm{N}$ and longitude $85^{\circ} 30^{\prime}-85^{\circ} 45^{\prime} \mathrm{E}$. Sector-2 constitutes the south western part of study area within the latitude $19^{\circ} 45^{\prime}-20^{\circ} 00^{\prime} \mathrm{N}$ and longitude $85^{\circ} 30^{\prime}-85^{\circ} 15^{\prime} \mathrm{E}$.

\section{Geological background}

The EGB occurs along the eastern coast of India (figure 1) and exposes diverse rock types that experienced granulite-grade metamorphism. In an earlier study, this terrain was longitudinally divided into four zones based on predominant lithological association, viz., Western Charnockite Zone (WCZ), Western Khondalite Zone (WKZ), Central Migmatite Zone (CMZ) and Eastern Khondalite Zone (EKZ) (Ramakrishnan et al 1998). On the other hand, Nd-isotopic mapping over the entire EGB and based on $\mathrm{Sm}-\mathrm{Nd}, \mathrm{Rb}-\mathrm{Sr}$ and $\mathrm{Pb}^{207}$ $\mathrm{Pb}^{206}$ isotopic data; Rickers et al (2001) identified four distinct crustal domains whose geographical boundaries grossly contradict the longitudinal subdivision. Domain 1 is located at the northern and southern parts of the Godavari Rift. However, there are notable differences in isotopic signatures between the northern (Domain 1B) and the southern domains (Domain 1A). Domain $1 \mathrm{~B}$ is characterized by strong Archaean protolith signatures (3.9-3.2 Ga for orthogneisses) while the Domain 1A preserves prominently Proterozoic protolith signatures and is characterized by homogeneous Ndmodel ages for orthogneisses $(2.5-2.3 \mathrm{Ga})$ and paragneisses $(2.8-2.6 \mathrm{Ga})$. The other three domains occur on the north of the Godavari Rift. Domain 3 occurs surrounding the Chilka Lake and shows homogeneous isotopic signatures of Proterozoic age (2.2-1.8 Ga for both orthogneisses and metasediments). Domain 2 is sandwiched between Domain 1 and Domain 3 and is isotopically the most heterogeneous one (2.5-2.1 Ga for metasediments and 3.2-1.8 Ga for orthogneisses). Domain 4 occurs at the northern extremity of the EGB close to the Mahanadi Rift with Nd-model ages 3.2 Ga for orthogneisses and 2.8-2.2 Ga for metasediments. In a more recent classification, the entire EGB was subdivided into several crustal provinces each containing several domains (Dobmeier and Raith 2003). It is notable that the crustal domains described by Rickers et al (2001) are different from those of Dobmeier and Raith (2003). Apart from contrasts in protolith histories, these domains and provinces are characterized by contrasting style and timing of deformation and petrological processes. It is now realized that evolution of EGB is to be reconciled in a time- and space-specific manner.

The Chilka Lake Domain of Dobmeier and Raith (2003) (part of the Domain 3 of Rickers et al 2001) occurs at the north-eastern part of the EGB where the present study is focused. This domain is characterized by the presence of a large body of anorthosite massif in the central region. The rocks exposed north-east of this anorthosite massif comprise high-grade granulites that witnessed multiple stages of deformation. Metapelitic granulites and charnockites of this area were previously studied by Sen et al (1995) who documented several phases of decompression and cooling-dominated $P-T$ path ensued from a peak condition of $\sim 1100^{\circ} \mathrm{C}$ and $>10$ Kbar. The geodynamic significance of such a metamorphic history is neither supported from that particular study, nor was substantiated by later work (as reviewed in Dasgupta and Sengupta 2003). Recent discovery of ultrahigh temperature (UHT) $\left(>1000^{\circ} \mathrm{C}\right)$ contact metamorphism near the anorthosite massif (Raith et al 2007; Sengupta et al 2008) provided additional petrological data, but could not resolve the uncertainty involving regional metamorphism and deformation pattern shown by all the rocks. A further bone of contention is the tectonic setting vis-àvis intrusion age of the anorthosite magma. The latter was initially fixed at ca. $792 \mathrm{Ma}$ (Krause et al 2001), but recent data of ca. $983 \mathrm{Ma}$ (Chatterjee et al 2008) suggest an older emplacement age. The tectonic setting of the anorthosite magmatism is a contentious issue as such magma normally is emplaced at extensional setting unlike the proposed scenario in the Chilka Lake Domain. However, the adjacent Bolangir anorthosite magmatism at ca. $933 \mathrm{Ma}$ is interpreted to occur at compressional setting (Dobmeier 2006).

Structural analysis around Chilka Lake anorthosite by previous researchers identified evidence of multiple deformational episodes. Bhattacharya et al $(1993,1994)$ identified imprints of three deformational episodes based on structural mapping and limited remote sensing data. They argued that the dominant NE-SW trending foliation $\left(S_{1}\right)$ of the Chilka Lake area can be correlated with regional trend of the EGB that was formed during $\mathrm{D}_{1}$ deformational event. On the other hand, a four-fold deformational style was proposed by others mostly based on satellite image analyses 
with limited ground checks (Dobmeier and Raith 2000; Dobmeier and Simmat 2002). Bhattacharya et al (1994) identified early compositional layering as $\mathrm{S}_{0}$ within khondalite, which eventually was isoclinally folded during $\mathrm{D}_{1}$ deformation. On the other hand, Dobmeier and Raith (2000) and Dobmeier and Simmat (2002) designated the rock suite of charnockite, enderbite and khondalite as 'migmatite complex'. According to these workers, the composite layering in this rock suite resulted from foliation-parallel injection of anatectic melt that was produced during partial melting of the lower crust. It is not clear how such anatectic melt could maintain uniform chemistry when produced from such a heterogeneous protolith. This compositional layering $\left(S_{0}\right)$ was tightly folded during $D_{1}$ deformation producing layer-parallel axial planar $\mathrm{S}_{1}$ fabric. Although both these working groups invoked a primary compositional plane $\left(\mathrm{S}_{0}\right)$, it is difficult to understand how such a primary structure could be preserved after high-temperature metamorphism that all the rocks underwent subsequently. $\mathrm{F}_{2}$ folding is isoclinal where $\mathrm{S}_{1}$ is partially transposed by $\mathrm{S}_{2}$ (Bhattacharya et al 1994). $\mathrm{F}_{3}$ folding is open and upright and the $\mathrm{S}_{3}$ plane is exposed as the fracture cleavage developed in both metapelites and the 'migmatite complex' along the axial plane of $\mathrm{F}_{3}$ folds (Bhattacharya et al 1994). Dobmeier and Raith (2000) opined that $S_{2}$ and $S_{3}$ are transposed in nature and are marked by fine-grained leucosome layer in the 'migmatite complex'. Dobmeier and Raith (2000) described a steeply dipping NNE-SSW trending $\mathrm{S}_{4}$ fabric which is formed during $\mathrm{F}_{4}$ folding of $\mathrm{D}_{4}$ deformational event in local-scale. Pegmatites are also emplaced along this $\mathrm{S}_{4}$ foliation. Geometry of this $\mathrm{F}_{4}$ folding is different from the last-formed $\mathrm{F}_{3}$ folding described by Bhattacharya et al (1994). There was also a controversy regarding the status of the patchy charnockites of Chilka Domain. The relict and vestigial ancestry of this rock (Bhattacharya et al 1994) was later refuted by Dobmeier and Raith (2000) who argued that charnockites are formed in situ in leptynite due to the channelization of synkinematic fluid during $\mathrm{D}_{3}$ deformational episode. $\mathrm{A}$ further problem stems from the status of the anorthosite plutonism as some argue its emplacement is post- $\mathrm{D}_{1}$ (Bhattacharya et al 1994), whereas others argue for a post- $\mathrm{D}_{2}$ emplacement (Dobmeier and Simmat 2002). The diverse opinions amongst the earlier researchers on these petrological and structural issues call for a re-evaluation and the present study aims at unravelling the structural evolution of the Chilka Lake granulites with new data. We would also strive to compare this structural interpretation with petrological and geochronological data available from this domain.

\section{Salient petrological features of the studied granulites}

Garnet-sillimanite gneiss or khondalite is the most common rock type of the studied area hosting a number of other rock types. Mineralogically, it contains quartz, alkali feldspar, garnet, sillimanite and opaque. The rock is strongly foliated with characteristic gneissic banding marked by alternate garnet-sillimanite-rich layer with quartzofeldspathic layers.

Garnetiferous quartzofeldspathic gneiss or leptynite is leucocratic rock composed of quartz, alkali feldspar, plagioclase, garnet and ilmenite with or without biotite. The rock is well-foliated with typical gneissic fabric. The gneissic fabric is defined by the concentration of mafic minerals such as garnet, biotite and ilmenite alternating with quartzofeldspathic bands.

Aluminous granulite occurs in two contrasting modes. One of its varieties is massive in appearance and podiform in occurrence. The massive variety of aluminous granulite occurs as centimetre-thick lenses, pinched and swollen layers and torn boudins within garnetiferous quartzofeldspathic gneisses. The immediate vicinity of the former is occupied by garnet-free quartzofeldspathic aggregates identified as leucosome fraction left out from the melanocratic layers/lenses of the aluminous granulite during partial melting. The aluminous granulite is characterized by coarse-grained garnet, orthopyroxene, plagioclase and cordierite grains with occasional presence of spinel and sapphirine. Local abundance of quartz and alkali-feldspar is discernable. Presence of biotite in this rock is conspicuous. The other variety of the aluminous granulite is distinctly migmatitic in nature. In the migmatitic variety, centimetre-millimetrethick garnet-sillimanite-ilmenite layer alternates with quartzofeldspathic layers.

Orthopyroxene-bearing quartzofeldspathic gneiss occurs as foliation-parallel layers and lenses within the garnetiferous quartzofeldspathic gneiss and their mode of occurrence is similar to those of massive variety of aluminous granulite. The rock is medium- to fine-grained containing orthopyoxene, plagioclase, alkali-feldspar, quartz and biotite. It shows strong gneissic fabric by alternate pyroxenerich and quartz-feldspar-rich millimetre-thick layering. The contact of this rock with the host garnetiferous quartzofeldspathic gneiss is mostly sharp without any presence of chilledmargin. Mineralogically, this rock is akin to the charnockite-enderbite group of rocks, but their igneous ancestry is not proved. In addition to this, patchy charnockites with broadly similar mineralogy are found within the garnetiferous quartzofeldspathic gneiss host. These charnockite 
patches locally pseudomorph the garnetiferous quartzofeldspathic gneiss, but the foliation in the latter could be traced in the former as continuous structure. These field features thus support the contention that the patchy charnockites were formed by in situ fluid-assisted metamorphic process as invoked by Dobmeier and Raith (2000).

Two-pyroxene granulite is another member of rock suite of garnetiferous quartzofeldspathic gneiss-aluminous granulite-orthopyroxene-bearing quartzofeldspathic rock ensemble. This rock contains both orthopyroxene and clinopyroxene along with plagioclase and ilmenite. Presence of quartz is nominal, but its abundance increases towards its contact with the host leptynite and migmatitic aluminous granulite. Presence of sulphide veins containing chalcopyrite and pyrrhotite is observed under microscopic study. The rock is massive, fine-grained and recrystallized in nature. Presence of possible chilled margin (now characterized by profuse concentration of garnet) suggests intrusive relation with the migmatitic aluminous granulite. Petrological and geochemical characteristics of this rock are discussed in detail by Bose et al (2011b).

\section{Regional-scale structures}

In the study area (north-northeast of Balugaon Massif anorthosites), the major mapable lithounits are

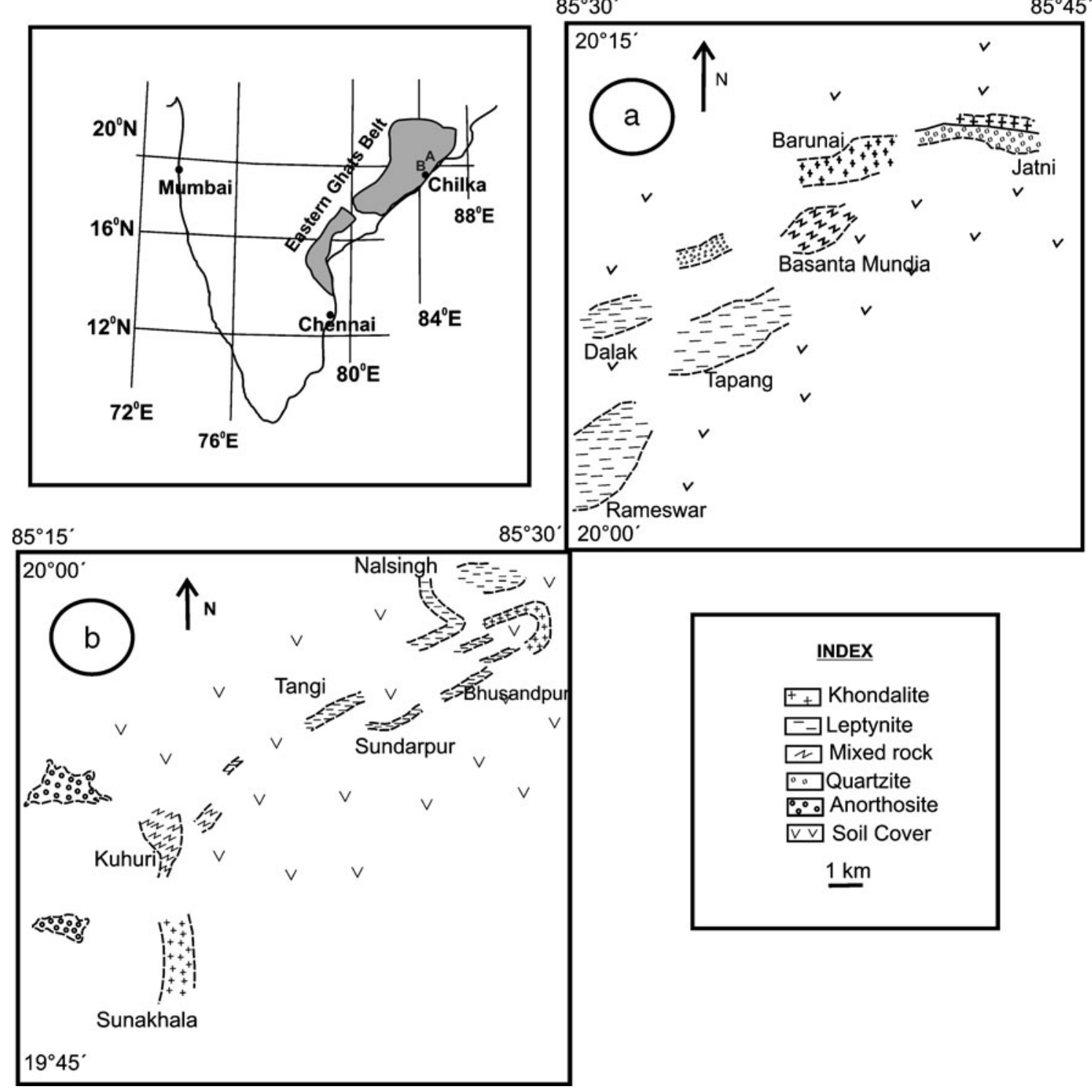

Figure 2. Lithological maps of the study area. (a) North-eastern sector (sector 1) and (b) south-western sector (sector 2). 
garnet-sillimanite gneiss (khondalite), garnetiferous quartzofeldspathic gneiss (leptynite) and a 'mixed rock suite' (composed of variable proportion of aluminous granulites, two-pyroxene granulites, garnetiferous quartzofeldspathic gneisses and charnockite-enderbite rocks) (figure 2a, b). An area covering $\sim 700 \mathrm{~km}^{2}$ has been structurally mapped in the scale of 1: 50,000 (figure 3a, b). The 'mixed rock suite' occurs as an enclave or a pocket within garnet-sillimanite gneiss and garnetiferous quartzofeldspathic gneiss in regional scale. Structurally, four phases of penetrative deformation are identified. The primary depositional surface $\left(\mathrm{S}_{0}\right)$ is not preserved either macroscopically or microscopically probably due to intensive multiphase deformation and transposition of $\mathrm{S}_{0}$ with successive structural fabrics in high-grade metamorphism. As a result, the transformation mechanism from $S_{0}$ to $S_{1}$ during $D_{1}$ is completely lost. The $\mathrm{S}_{1}$ fabric, formed because of $\mathrm{D}_{1}$ deformational event is rarely preserved in microscopic scale in aluminous granulites of 'mixed rock suite'. So, signatures of $\mathrm{D}_{1}$ deformation could only be studied from microstructures. $\mathrm{S}_{1}$ acts as a form-surface which was affected by later deformational events $\left(\mathrm{D}_{2}-\mathrm{D}_{4}\right)$. However, absence of $\mathrm{S}_{1}$ in outcrop- to regional-scale precludes identification of the second folding $\left(\mathrm{F}_{2}\right)$ during structural mapping. On the contrary, the pervasive penetrative $\mathrm{S}_{2}$ gneissic foliation, developed during $\mathrm{D}_{2}$ deformation is present in all the rock units. The gneissic foliation
$\mathrm{S}_{2}$ in khondalite, leptynite and 'mixed rock suite' are regionally folded during $\mathrm{D}_{3}$ deformational event. The overall disposition of the strike of $\mathrm{S}_{2}$ gneissic foliation systematically varies from $\mathrm{E}-\mathrm{W}$ to NE-SW and finally to $\mathrm{N}-\mathrm{S}$ orientation from the northeastern part to the southwestern part of the study area (figure 3a, b). Regional-scale close to tight fold closures $\left(\mathrm{F}_{3}\right)$ are envisaged from systematic variation of the $\mathrm{S}_{2}$ foliation. The $\mathrm{F}_{3}$ folds are gently-plunging inclined in nature. $\mathrm{F}_{3}$ fold axis regionally trends along $\mathrm{NE}-\mathrm{SW}$ with plunge reversal with variable amounts of plunge (from $2^{\circ}$ up to $40^{\circ}$ ). The inter-limb angles vary regionally and the $\mathrm{F}_{3}$ folds are open at southern part of the area. The newly-developed $\mathrm{S}_{3}$ foliation formed during $D_{3}$ is almost parallel to $S_{2}$ gneissic foliation at limbs of tight to isoclinal $\mathrm{F}_{3}$ folds on outcrop-scale. Therefore, the regional penetrative foliation can be designated as 'transposed $\mathrm{S}_{2} / \mathrm{S}_{3}$ fabric' except at the regional $\mathrm{F}_{3}$ fold closures (such as in Basanta Mundia). The absence of $\mathrm{F}_{2}$ folding in outcrop-scale is conspicuous and only observed under microscopic scale. The general NE-SW trend of the $\mathrm{S}_{2}$ foliation is deflected near Kuhuri giving a southern fold closure adjacent to Balugaon Massif anorthosite complex (figure 3b). The last $\mathrm{D}_{4}$ deformational event is evident from the development of $\mathrm{F}_{4}$ folds on either $\mathrm{S}_{2}$ or transposed $\mathrm{S}_{2} / \mathrm{S}_{3}$ foliation that interfere with $\mathrm{F}_{3}$ throughout the area in outcrop- to regional-scale. The variable orientations of the $\mathrm{F}_{3}$ fold axes and axial traces on

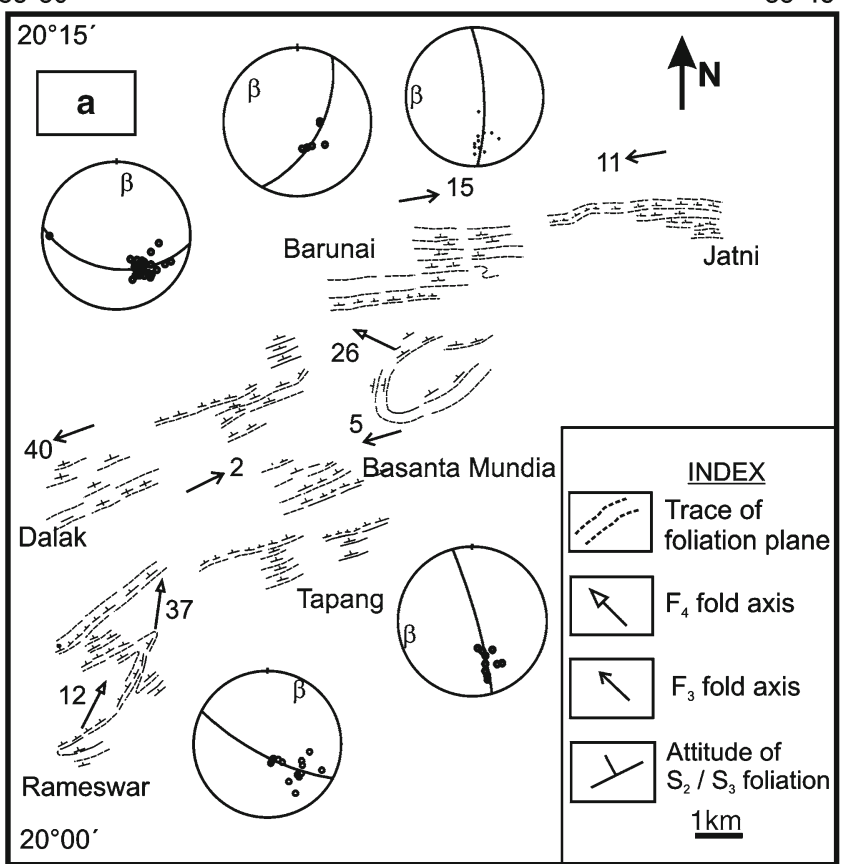

$85^{\circ} 15^{\prime}$

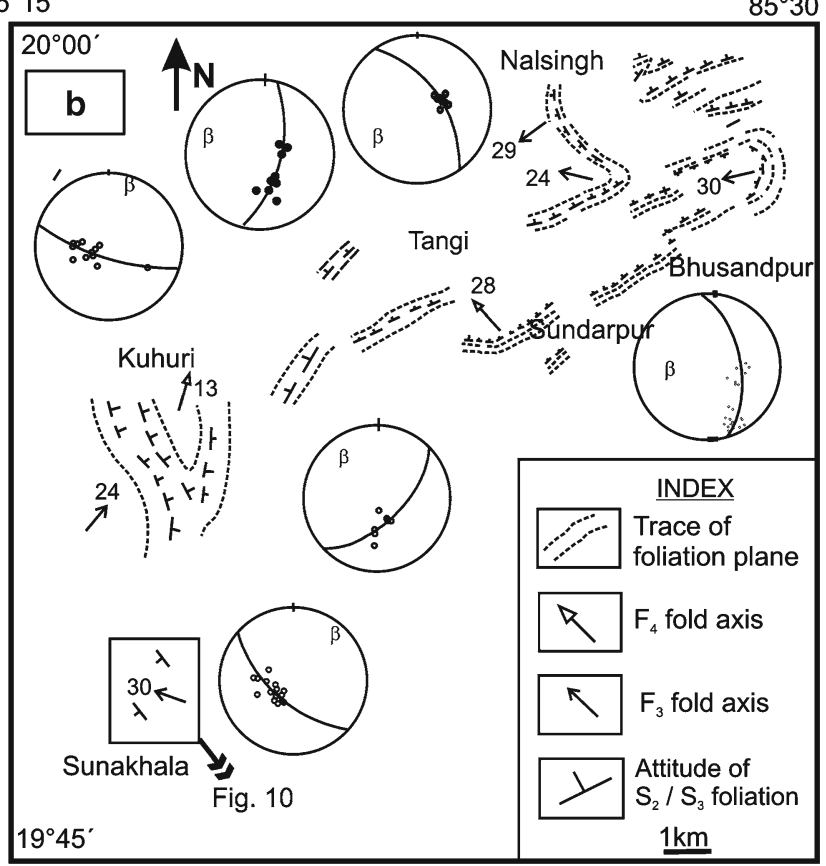

Figure 3. Structural maps of the study area. (a) North-eastern sector (sector 1) and (b) south-western sector (sector 2). 
regional scale (figure $3 \mathrm{a}, \mathrm{b}$ ) are probably due to modifications during later deformational event $\left(\mathrm{D}_{4}\right)$. However, the general trend of $\mathrm{F}_{4}$ axes is broadly in N-S to NW-SE direction on regionalscale, whereas the $\mathrm{F}_{4}$ axial traces in some outcrops are parallel to $\mathrm{N}-\mathrm{S}$. $\mathrm{S}_{4}$ was developed during $\mathrm{D}_{4}$ and appears as spaced cleavage in outcrop-scale. Detailed structural studies with mapping of the area in regional scale $(1: 50,000)$, outcrop-scale studies with plane paper mapping in amplified scale (1:100), vertical section drawing and sector-wise stereographic plotting have been carried out to decipher the interference pattern of $\mathrm{F}_{3}$ and $\mathrm{F}_{4}$ folds. The interference pattern of $\mathrm{F}_{3}$ and $\mathrm{F}_{4}$ on $\mathrm{S}_{2}$ foliation as well as transposed $\mathrm{S}_{2} / \mathrm{S}_{3}$ shows the non-plane non-cylindrical to plane noncylindrical patterns in different sectors depending on the initial geometry of $\mathrm{F}_{3}$ folding and localscale strain variation. Evidence of superimposed deformation between $\mathrm{F}_{3}$ and $\mathrm{F}_{4}$ are preserved in outcrop-scale in aluminous granulites of 'mixed rock suite', khondalite and leptynite. Only a weak gneissic foliation, visible in anorthosite, at its contact of the above-mentioned granulites in southwestern part of the study area is oriented broadly either in E-W or NW-SE direction. The foliation in anorthosites was presumably developed during the last intense deformation $\mathrm{D}_{3}$ that gave rise to a strong transposed $\mathrm{S}_{2} / \mathrm{S}_{3}$ gneissic foliation in the granulites. Weak variation in foliation traces in anorthosites is probably the result of the $\mathrm{D}_{4}$ deformation.

\section{Mesoscopic and microscopic structures}

Imprints of four penetrative deformations are observed and have been designated as $D_{1}, D_{2}$, $\mathrm{D}_{3}$ and $\mathrm{D}_{4}$. Development of $\mathrm{S}_{1}$ foliation during $\mathrm{D}_{1}$ event and development of $\mathrm{F}_{2}$ folds on $\mathrm{S}_{1}$ foliation during $D_{2}$ event are documented only from microstructures. Development of $\mathrm{S}_{2}$ gneissic foliation and successive structural signatures corresponding to $\mathrm{D}_{2}-\mathrm{D}_{4}$ are evident in mesoscopicas well as megascopic-scale. Later folds are designated as $\mathrm{F}_{3}$ and $\mathrm{F}_{4}$ corresponding to $\mathrm{D}_{3}$ and $\mathrm{D}_{4}$ deformational events respectively, whereas the axial planar foliations of corresponding folds are termed as $\mathrm{S}_{3}$ and $\mathrm{S}_{4}$, respectively. The characteristic metamorphic assemblages developed during different stages of deformational history are also described here in detail to correlate these two processes. From the microstructural study, it is evident that $\mathrm{M}_{2}-\mathrm{D}_{2}$ assemblage was developed during the peak metamorphic stage, whereas $\mathrm{M}_{3}-\mathrm{D}_{3}$ and $\mathrm{M}_{4}-\mathrm{D}_{4}$ assemblages were developed during retrograde stage.

\section{$5.1 D_{1}$ deformation and pre-peak $M_{1}-D_{1}$ assemblage}

The signature of $\mathrm{S}_{0}$, the primary compositional banding is completely lost and earliest planar fabric, identifiable only under microscope, is a schistosity, which is now designated as $\mathrm{S}_{1}$. This earliest planar fabric $\mathrm{S}_{1}$ is absent in the macroscopic- to megascopic-scale in all rock units due to overprinting of subsequent deformation under high-grade metamorphic conditions.

Microscopically, traces of $S_{1}$ fabric are preserved in the aluminous granulites. Inclusion trails of sillimanite are present within garnet porphyroblasts of both the types of aluminous granulites. In the massive variety, such garnet porphyroblasts locally also contain rounded inclusion of quartz, plagioclase and biotite. The included sillimanitebiotite-ilmenite assemblage within garnet porphyroblasts in the migmatitic variety is often folded (figure 4a). This internal foliation composed of biotite, sillimanite, ilmenite and quartz, represents the traces of an earlier planar fabric $\left(\mathrm{S}_{1}\right)$. Thus, the early $\mathrm{M}_{1}-\mathrm{D}_{1}$ assemblage is broadly represented by biotite-sillimanite-quartz-plagioclase developed during pre-peak metamorphic conditions.

\section{$5.2 D_{2}$ deformation and peak $M_{2}-D_{2}$ assemblage}

Mesoscopically, a penetrative foliation $\left(\mathrm{S}_{2}\right)$, defined by gneissic fabric has been developed during $\mathrm{D}_{2}$ deformational event. Folded internal foliations have been documented only under microscope (figure 4a). Gneissic foliation, $\mathrm{S}_{2}$ is developed nearly in all the rock units present in the study area. In the aluminous granulites, $\mathrm{S}_{2}$ fabric is characterized by alternate banding between porphyroblastic garnet-sillimanite-cordierite and quartzofeldspathic layers. In khondalite, this foliation is defined by alternate garnetsillimanite \pm biotite bearing mesocratic and quartzofeldspathic leucocratic layers. On the other hand, in leptynite, $\mathrm{S}_{2}$ fabric is characterized by garnet-rich mesocratic layer and quartzofeldspathic leucosomal layers. In regional-scale, the orientation of $\mathrm{S}_{2}$ gneissic foliation systematically varies from northeast part of the study area to the southwestern part, which resulted from superimposition of later deformational events, discussed later.

Microscopically, the peak assemblage $\left(\mathrm{M}_{2}\right)$ is represented by porphyroblastic orthopyroxenegarnet-cordierite-plagioclase in massive aluminous granulites which is surrounded by quartzofeldspathic leucosome. In the migmatitic aluminous granulite, peak assemblage is represented by 

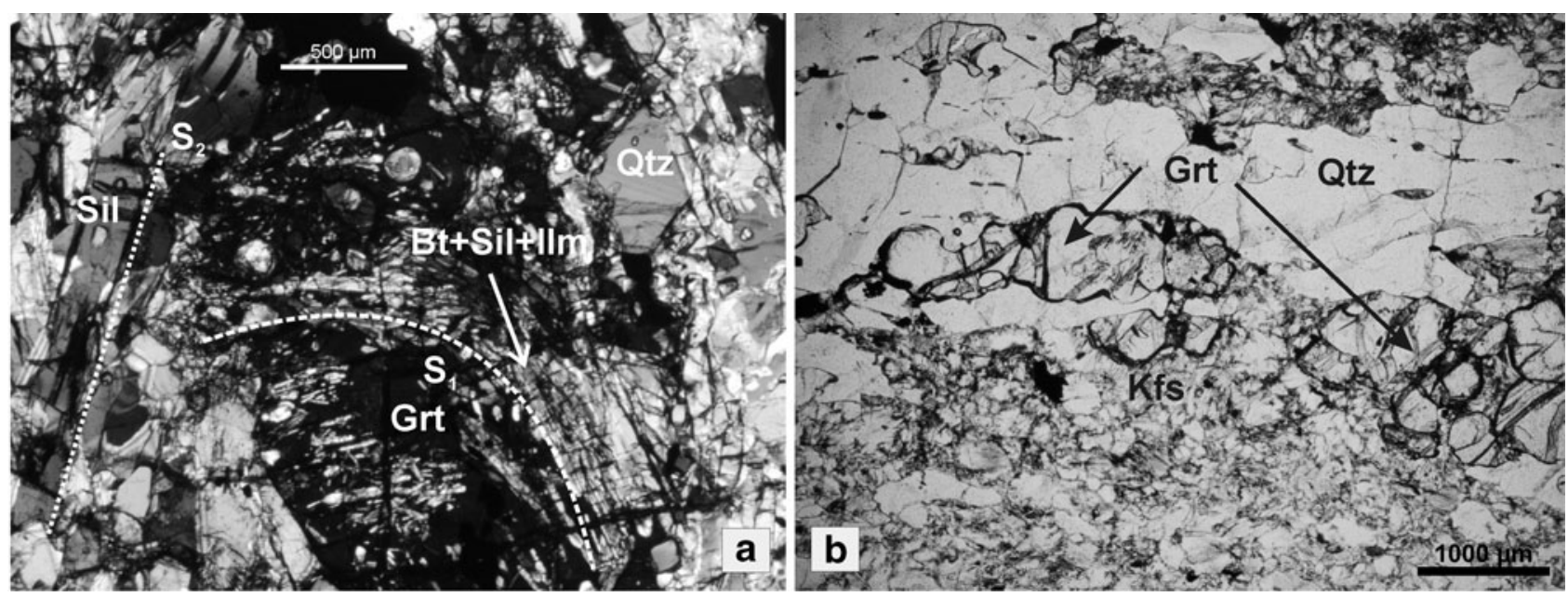

Figure 4. Photomicrographs of studied granulites. (a) Sillimanite-biotite-ilmenite (Sil+Bt+Ilm) S 1 -assemblage within garnet (Grt) porphyroblast in the migmatitic variety of aluminous granulite. Note the folded nature of $\mathrm{S}_{1}$ and its relationship with $\mathrm{S}_{2}$ in the studied section. (b) Garnets porphyroblast are flattened along the foliation in leptynite.

garnet-sillimanite-ilmenite-bearing dark layers alternating with quartzofeldspathic leucosome layers. The leucocratic layers in both the varieties of aluminous granulites are composed of quartzperthite-plagioclase. Their relative proportion varies considerably in different samples.

In the charnockite/enderbite gneiss, a weak foliation is defined by the flattened grains of quartz, orthopyroxene and feldspar grains whereas in the leptynite, this foliation is characterized by flattened quartz and feldspar grains. Garnet porphyroblasts occasionally show flattening along the foliation in this rock (figure $4 \mathrm{~b}$ ).

Two-pyroxene granulites are characterized by a weak foliation defined by the assemblage orthopyroxene-clinopyroxene-plagioclase-ilmenite, which were stabilized at peak metamorphic condition. Minor amount of quartz is also present.

\section{$5.3 D_{3}$ deformation and post-peak $M_{3}-D_{3}$ assemblage}

In the outcrop-scale, all the lithounits systematically show folded $\mathrm{S}_{2}$ assemblage in the same style as the regional folding. The $F_{3}$ folds are tight to isoclinal, gently inclined and gently plunging (fold axis plunges $18^{\circ}$ towards $260^{\circ}$ ) on outcropscale in khondalite near Barunai (figure 5a). Attitude of fold axes also indicates plunge reversal $\left(15^{\circ}\right.$ towards $\left.85^{\circ}\right)$. Newly developed $\mathrm{S}_{3}$ planar fabrics due to this deformational event are different for different lithounits. In khondalite, $\mathrm{S}_{3}$ fabric is defined by flattening of preexisting quartz and feldspar grains axial planar to the $\mathrm{F}_{3}$ folds (figure $5 \mathrm{~b}$ ). At the hinge zones of the $\mathrm{F}_{3}, \mathrm{~S}_{2}$ and $\mathrm{S}_{3}$ are at high angles to each other. On the other hand, $S_{2}$ and $S_{3}$ are lying parallel to each other at the limb zones of the $\mathrm{F}_{3}$ isoclinal folds. In outcrop-scale, the form surfaces $\left(\mathrm{S}_{2}\right.$ gneissic foliation) of $\mathrm{F}_{3}$ folds were tectonically transposed with the newly developed axial planar foliation, $\mathrm{S}_{3}$. This tectonic transposition of $\mathrm{S}_{2} / \mathrm{S}_{3}$ foliations over large area is the general character. The segregated granitic bands of gneissic compositional banding suffered extensional fracturing at high angles to the transposed $\mathrm{S}_{2} / \mathrm{S}_{3}$ foliation. At Basanta Mundia, the $\mathrm{S}_{2}$ gneissic foliation in aluminous granulites is folded to develop $\mathrm{F}_{3}$ small folds where garnetcordierite-bearing leucosome bands are segregated axial planar to these folds (figure 5c). Similar isoclinal recumbent to gently inclined subhorizontal to gently plunging $\mathrm{F}_{3}$ folds are also observed in leptynite near Kuhuri. Coarse-grained granitic materials were segregated or emplaced parallel to this transposed $\mathrm{S}_{2} / \mathrm{S}_{3}$ foliation and occasionally intersect the $\mathrm{F}_{3}$ fold hinges (figure $5 \mathrm{~d}$ ). Near Jatni, $\mathrm{S}_{2}$ gneissic foliation in khondalite/quartzite shows small isoclinal, steeply inclined $\left(65^{\circ}\right)$, moderately plunging $\left(48^{\circ}\right)$ folds. Axial planar fabric $\left(\mathrm{S}_{3}\right)$ is developed which becomes parallel to $\mathrm{S}_{2}$ due to tectonic transposition (figure $5 \mathrm{e}$ ). The quartz-rich band showed pinch-and-swell structures during this deformational event. The near-perpendicular relationship between fold and boudin axes (deduced from bending fold orientations) suggests that the boudinage occurs due to the extension parallel to fold axis. At Kuhuri, the migmatitic rock ensemble consisting of leptynite, charnockite/enderbite and aluminous granulites (mapped as mixed unit) are strongly folded to exhibit transposed $\mathrm{S}_{2} / \mathrm{S}_{3}$ gneissic foliation where the competent restitic aluminous granulite bands are boudinaged (figure $5 \mathrm{f}$ ). The individual boudins as well as boudinaged 

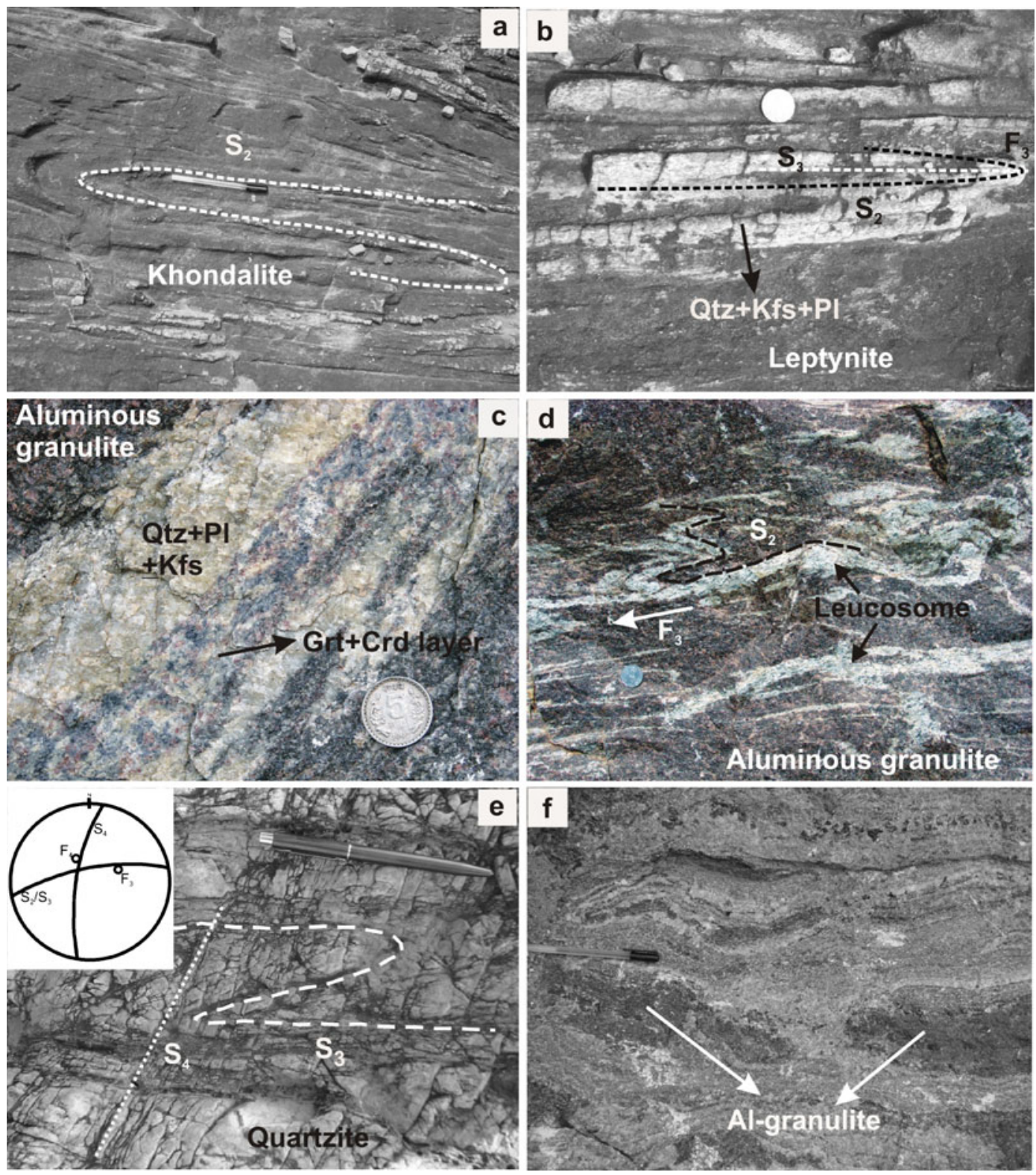

Figure 5. Field photographs of the studied granulites. (a) Tight to isoclinal $\mathrm{F}_{3}$ fold in khondalite near Barunai, (b) $\mathrm{S}_{3}$ fabric defined by flattened quartz and feldspar grain axial planar to isoclinal $\mathrm{F}_{3}$ fold in khondalite near Barunai, (c) garnetcordierite-bearing leucosomal part axial planar to $\mathrm{F}_{3}$ small folds in aluminous granulites, (d) isoclinal recumbent gently plunging $\mathrm{F}_{3}$ folds in leptynite, (e) small isoclinal, steeply inclined, moderately plunging folds within khondalite/quartzite band showing transposed $\mathrm{S}_{2} / \mathrm{S}_{3}$ fabric and $\mathrm{S}_{4}$ as spaced cleavage (inset showing the pole plots of fabric as well as axial orientations) and (f) folded boudins of aluminous granulite encased in leptynite.

layers are folded during subsequent deformation $\left(\mathrm{D}_{4}\right)$. The cordierite-bearing leucosome layers are concentrated at the neck zone of the folded boudins. Occasionally, cordierite-bearing quartzofeldspathic layers are found to be segregated within boudins as well as its surroundings as network veins. The boudinage process appears to post-date the segregation.

Minerals stabilized during the peak metamorphic stage show partial to complete decomposition to intergrowths surrounding the $\mathrm{M}_{2}$ phases. In the massive-type aluminous granulite, porphyroblastic garnet commonly exhibits partial to complete decomposition texture surrounding it in different samples. Delicate symplectites of orthopyroxene and cordierite often corrodes and embays garnet grains. In other samples, coarse garnet shows breakdown to coarse intergrowth of sapphirine, spinel, cordierite and plagioclase (figure $6 a)$. Garnet also shows breakdown to sapphirine- 
cordierite. In few samples, garnet is surrounded by a double-layer corona containing spinel-cordierite and sapphirine-cordierite symplectite, respectively (figure 6b). Garnet also shows partial breakdown to skeletal to symplectic intergrowth of spinelorthopyroxene-cordierite in other samples. Such complex intergrowth textures are considered to be a product of $\mathrm{M}_{3}$ event.

All the porphyroblastic phases in both the varieties of aluminous granulites show evidence of grain-scale deformation, viz., partial grain refinement, undulosity, bending of cleavage traces as well as fracturing. In leucosome layers, quartz grains show lobate and cuspate mutual contacts (figure 6c). This kind of mutual contact between grains are characteristic of high-temperature metamorphic condition where the grain boundaries become highly mobile and may sweep the material in any direction to remove dislocations and subgrain boundaries (Gower and Simpson 1992;
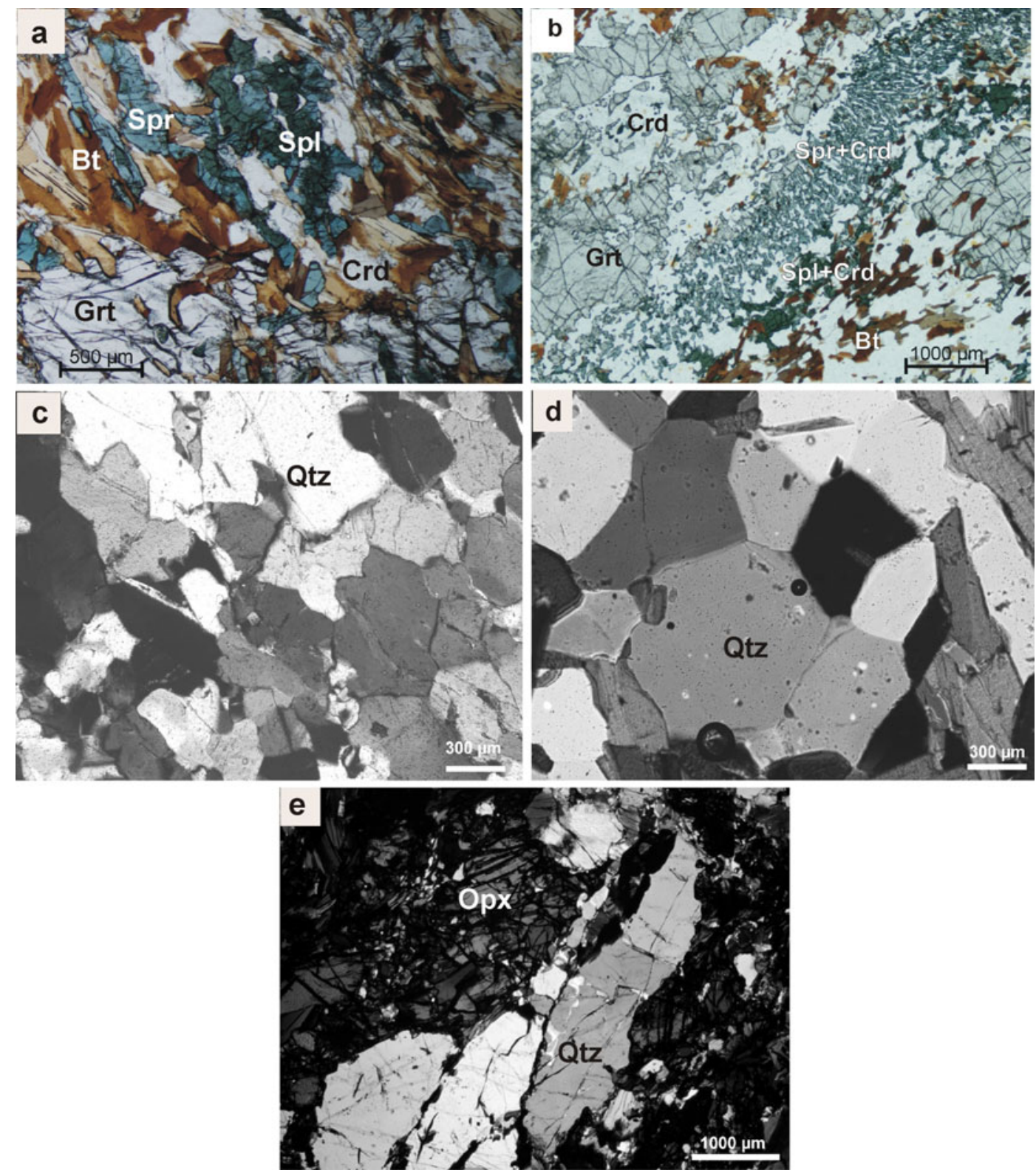

Figure 6. Photomicrographs showing textures of the studied granulites. (a) Coarse garnet (Grt) shows breakdown to coarse intergrowth of sapphirine (Spr), spinel ( $\mathrm{Spl}$ ), cordierite (Crd) in aluminous granulite, (b) garnet (Grt) is surrounded by a double layer corona containing spinel+cordierite $(\mathrm{Spl}+\mathrm{Crd})$ and sapphirine+cordierite (Spr+Crd) symplectite, respectively, (c) Individual quartz grain shows lobate contact to each other in leptynite, (d) quartz grain underwent recrystallization as evident from polygonal grain boundary, (e) ribbon-shaped quartz grain in charnockitic gneiss. 
Passchier and Trouw 2005). Such lobate shape further suggests that recrystallization of quartz grains is mainly guided by high-temperature Grain Boundary Migration (GBM). Quartz and feldspar underwent static recrystallization as evident from polygonal grain boundaries (figure 6d). The process responsible could be Grain Boundary Area Reduction (GBAR). Quartz grains in both charnockite/enderbite and leptynite are occasionally ribbon-shaped (figure 6e). Undulose extinction and cuspate grain boundaries are also common in quartz and feldspar grains.

All these characteristic features indicate that the peak assemblage was subjected to crystalplastic deformation during $\mathrm{D}_{3}$ deformational event.

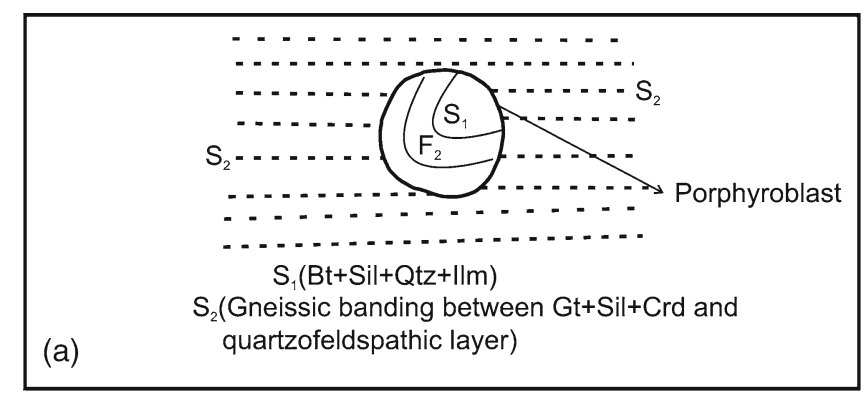

(b)
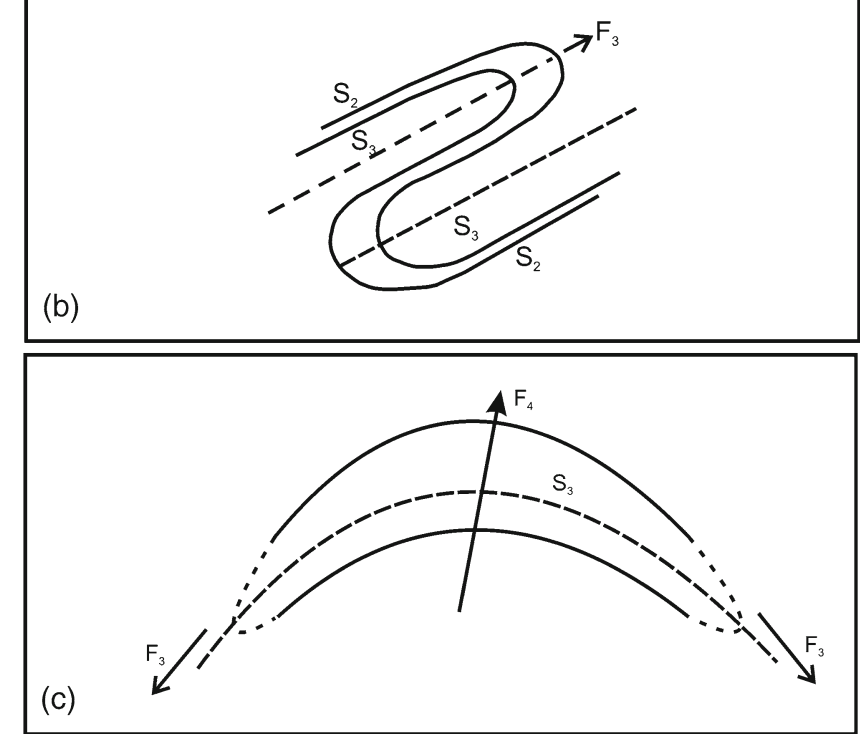

Figure 7. Schematic diagram showing successive development of different stages of deformation and associated fabric. (a) $\mathrm{S}_{2}$ fabric is a penetrative gneissic foliation defined by porphyroblastic phases. $\mathrm{F}_{2}$ fold is only identified in microscopic scale within porphyroblastic phases. (b) Tight to isoclinal $\mathrm{F}_{3}$ fold on axial-plane perpendicular profile section. $\mathrm{S}_{3}$ fabric is axial planar to $\mathrm{F}_{3}$ fold in outcrop scale. Note that $\mathrm{S}_{2}$ and $\mathrm{S}_{3}$ are parallel to each other except in hinge zone of $\mathrm{F}_{3}$ fold. This is designated as transposed $\mathrm{S}_{2} / \mathrm{S}_{3}$ fabric. (c) Horizontal section showing $\mathrm{D}_{4}$ deformation event that regionally folded the transposed $\mathrm{S}_{2} / \mathrm{S}_{3}$ fabric. $\mathrm{S}_{4}$ is defined by a spaced cleavage on outcrop scale.

\section{$5.4 D_{4}$ deformation and $M_{4}-D_{4}$ assemblage}

The $\mathrm{S}_{2}$ gneissic foliation along with the transposed $\mathrm{S}_{2} / \mathrm{S}_{3}$ fabric was affected by the $\mathrm{D}_{4}$ deformation. Overall orientation of $\mathrm{F}_{4}$ axial plane is along NW-SE direction though it is slightly variable in regional-scale. The $\mathrm{F}_{4}$ folds are characteristically open and upright to steeply inclined, with variable amount of plunge $\left(12^{\circ}-53^{\circ}\right)$ towards NW direction (figure 5e, inset). The deformation is too weak to develop any penetrative fabric in the rocks except occurrences of spaced cleavage along axial planes of $\mathrm{F}_{4}$ in some instances. This last deformational event modified the $\mathrm{F}_{3}$ folds depending on variable orientation of folded $S_{2}$ and $S_{2} / S_{3}$ transposed fabric, inter-limb angle of $\mathrm{F}_{3}$ folding, orientation of local strain ellipsoid and its relation with variable $\mathrm{F}_{3}$ fold axes. Attitude of $\mathrm{F}_{4}$ fold axes are also variable in large-scale. Angular relationship exists between axial planes of $\mathrm{F}_{3}$ and $\mathrm{F}_{4}$ folds. The regional disposition of $\mathrm{F}_{3}$ and $\mathrm{F}_{4}$ folds clearly documents overall non-plane non-cylindrical interference pattern
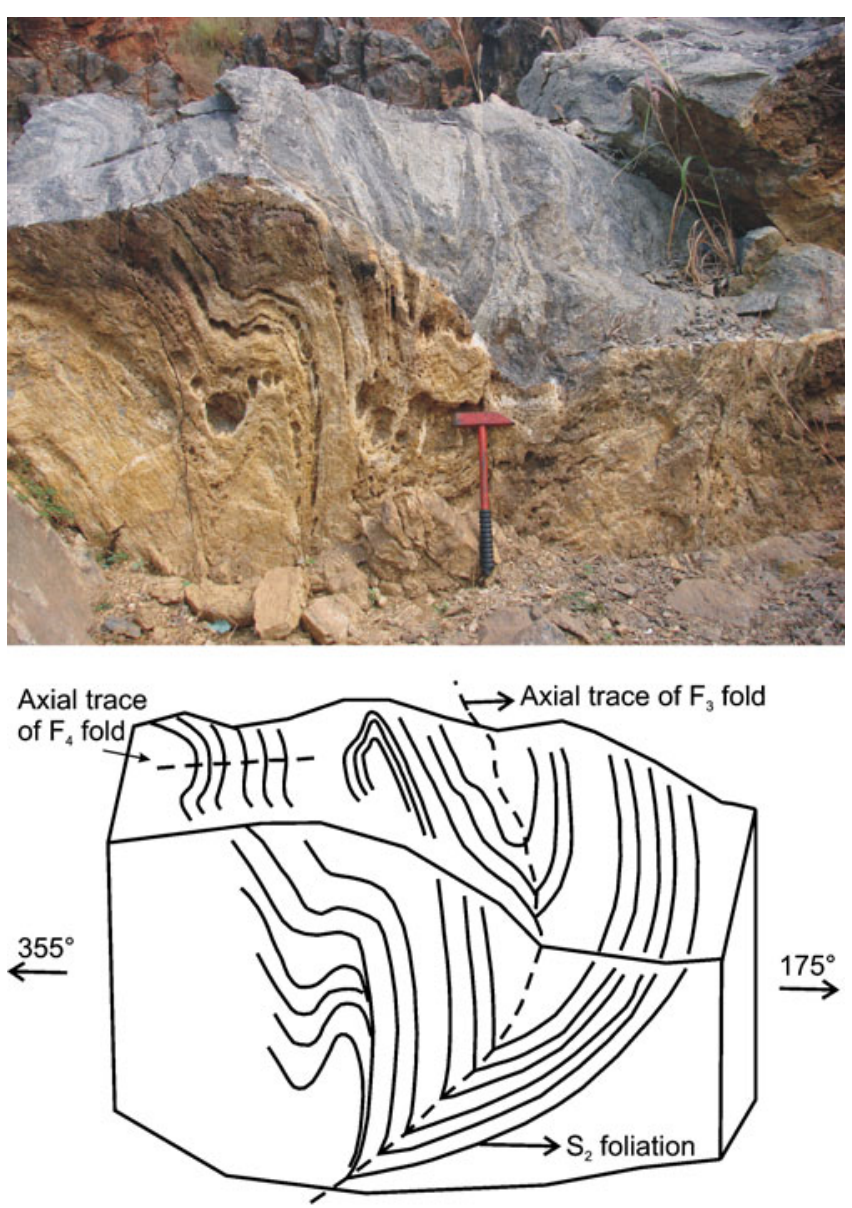

Figure 8. Non-plane non-cylindrical fold interference pattern of $\mathrm{F}_{3}$ and $\mathrm{F}_{4}$ near Basanta Mundia. Upper figure represents the field photograph while the lower figure represents the hand sketch of same outcrop showing disposition of $\mathrm{S}_{2}$ foliation, $\mathrm{F}_{3}$ fold, $\mathrm{S}_{3}$ foliation and $\mathrm{S}_{4}$ foliation. 
(figure 3a, b). Schematic development of successive stages of deformation is illustrated in figure 7 . $\mathrm{D}_{4}$ deformation causes rotation of the early megascopic $\mathrm{F}_{3}$ fold axes as evident from plunge reversal of $\mathrm{F}_{3}$ in outcrop and also from the regional map pattern. Such rotation of the $F_{3}$ fold axis is not uniform in nature across the whole area.

Near Jatni, open, steeply inclined plunging $\mathrm{F}_{4}$ folds are shown by the transposed $\mathrm{S}_{2} / \mathrm{S}_{3}$ gneissic foliation in khondalite. Spaced cleavage develops along axial plane to $\mathrm{F}_{4}$ fold with $\mathrm{N}-\mathrm{S}$ trend having moderate to steep dip (varies from $65^{\circ}-70^{\circ}$ ) inclined towards west (figure $5 \mathrm{e}$ ). The fold interference pattern of $\mathrm{F}_{3}$ and $\mathrm{F}_{4}$ also systematically varies in outcrop-scale from northeast to southwest of the area depending upon the initial fold geometry and local disposition with respect to $\mathrm{F}_{4}$. Near Basanta Mundia, the interference pattern is shown by the folding of the aluminous granulites exposed in two orthogonal sections; one broadly perpendicular to initial $\mathrm{F}_{3}$ fold axis and other one broadly parallel to it. Axial trace of $\mathrm{F}_{3}$ fold shows curvature on fold axis, perpendicular section indicates its non-plane nature and its non-cylindrical character is evident on the section that is at low angle to the fold axis (figure 8 ). $\mathrm{F}_{3}$ plunges $12^{\circ}$ towards $260^{\circ}$, whereas $\mathrm{F}_{4}$ axial plane strikes along $105^{\circ}$ and dips $70^{\circ}$ towards north. The initial gently plunging, tight to isoclinal inclined $\mathrm{F}_{3}$ folds were modified during interference of an open upright $\mathrm{F}_{4}$ folds at an angle to it. At Kuhuri, non-plane non-cylindrical interference pattern of $F_{3}$ and $F_{4}$ are also observed on two orthogonal sections in leptynite. On vertical section, occurring at high angle to $\mathrm{F}_{3}$ fold axis, the $\mathrm{F}_{3}$ folds are tight to isoclinal, gently plunging $\left(10^{\circ}\right.$ towards $90^{\circ}$ ), recumbent to gently inclined. In near horizontal plane, the transposed $\mathrm{S}_{2} / \mathrm{S}_{3}$ gneissosity are folded by subsequent $\mathrm{D}_{4}$ deformation forming a non-plane non-cylindrical interference pattern (figure 9). The nature of $\mathrm{F}_{4}$ is open upright gently plunging $\left(15^{\circ}\right.$ towards $\left.30^{\circ}\right)$. However, type- 2 interference pattern is a common feature of this area and is evident in regional-scale and in most of the outcrop sections. The $\mathrm{F}_{3} / \mathrm{F}_{4}$ interference pattern near Sunakhala exhibits plane non-cylindrical, i.e., type-1 in nature. The interference pattern is shown in a plane paper map of the outcrop with a scale of 1:100 (figure 10). $\mathrm{F}_{4}$ folds were developed on $\mathrm{S}_{2}$ at an angle with a set of open $\mathrm{F}_{3}$ folds forming this kind of interference. It is evident that style of interference pattern is variable in outcrop-scale depending upon the initial fold geometry and probably local strain ellipse. Moreover, the individual boudins as well as boudinaged layers of aluminous granulites hosted within leptynite, developed during $\mathrm{D}_{3}$ event, have been subsequently folded during $\mathrm{F}_{4}$ event on Kuhuri quarry face (figure $5 \mathrm{f}$ ).

The $\mathrm{M}_{2}$ and $\mathrm{M}_{3}$ assemblages are overprinted by biotite-bearing assemblages at post-peak metamorphic condition. Most commonly, garnet and
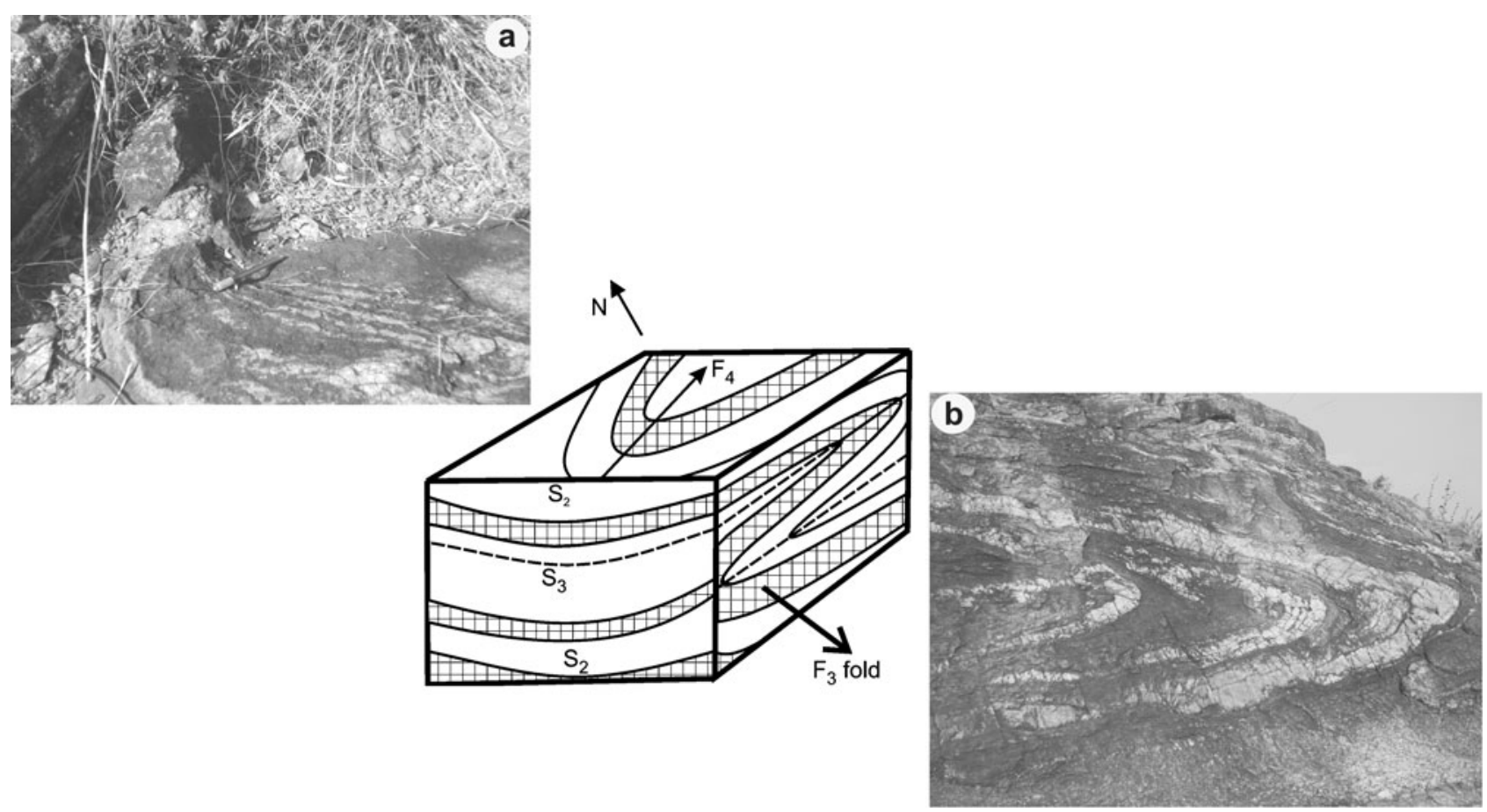

Figure 9. Schematic block diagram of the fold interference patterns in Kuhuri area. The field photographs of the horizontal surface and vertical section are shown in (a) and (b), respectively. 


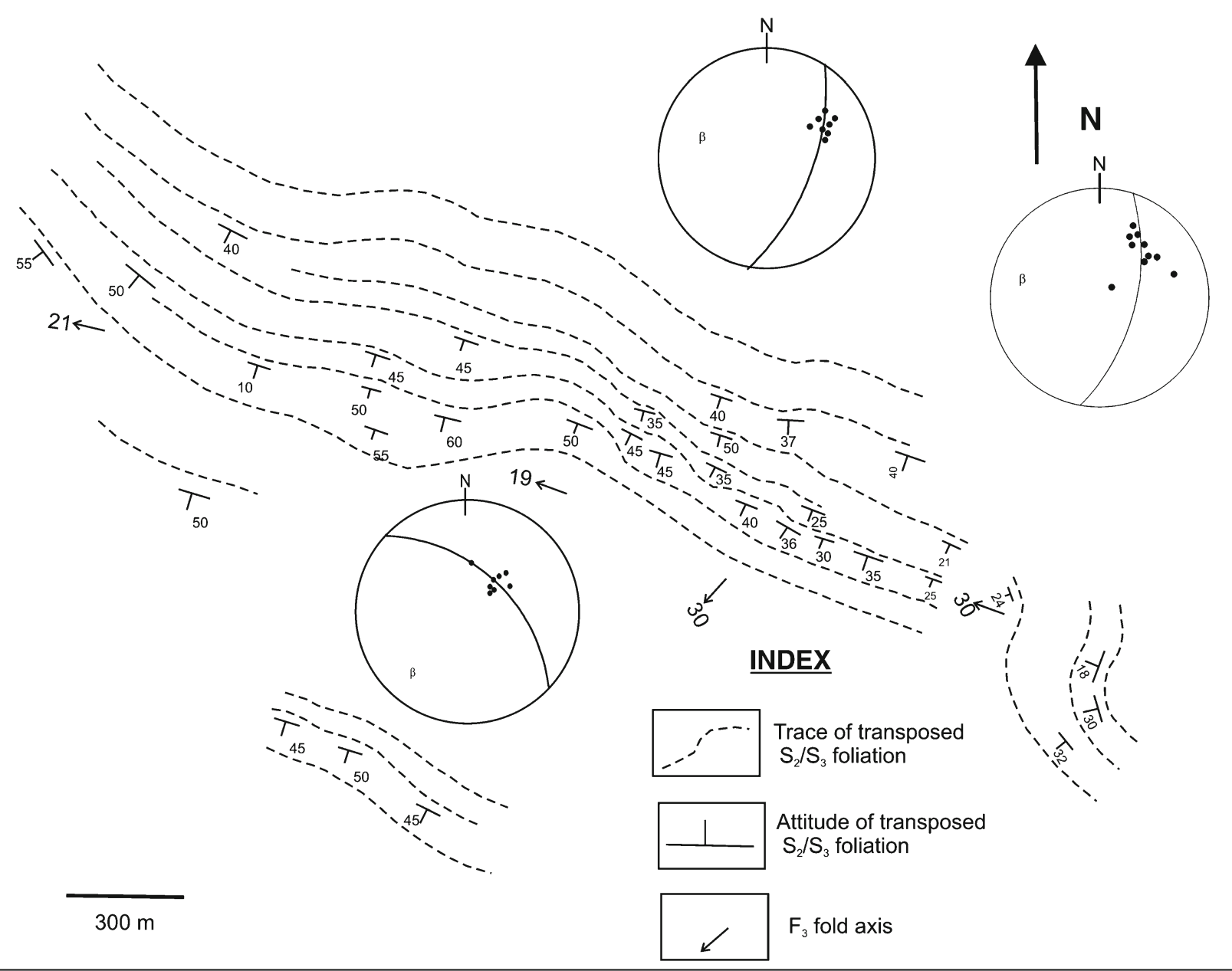

Figure 10. Plane table map near Sunakhala area in scale of 1:100. The mapped rock is khondalite showing the plane non-cylindrical interference patterns of $\mathrm{F}_{3}$ and $\mathrm{F}_{4}$.

orthopyroxene porphyroblasts are replaced by coarse- to medium-grained biotite flakes. Biotite growth is post-tectonic with respect to $\mathrm{D}_{2}$ garnet porphyroblast. In pyroxene granulites, amphibole growth is identified as $\mathrm{D}_{4}$ assemblages.

\section{Discussion}

Bhattacharya et al (1994) argued that the primary compositional layering $\left(\mathrm{S}_{0}\right)$ is preserved in khondalite. On the other hand, Dobmeier and Raith (2000) and Dobmeier and Simmat (2002) proposed that the compositional layering $\left(\mathrm{S}_{\mathrm{SL}}\right)$ actually represents a package of enderbite, khondalite and composite layers of leucosome and restite in the migmatitic aluminous granulites, all of which were derived through partial melting of metasediments. Bhattacharya et al (1994) opined that the $\mathrm{S}_{1}$ fabric developed in khondalites and charnockites due to $F_{1}$ folding represents the major tectonic trend which is broadly parallel to the dominant trend of Eastern Ghats granulites belt. They claimed that the study area evolved through multiple phases of deformation (Bhattacharya et al 1994) and metamorphism (Sen et al 1995), where peak metamorphic condition was attained as $1100^{\circ} \mathrm{C}$ and $>10$ Kbar. Survival of the primary sedimentary banding is difficult in this kind of high-grade metamorphic terrain with multiple phases of deformation accompanied by partial melting and development of metamorphic segregation. Unless proved using any field or laboratory techniques (such as petrography), the preserved compositional banding in high-grade metamorphic rocks may be considered as metamorphic compositional banding. On the contrary, our field observation as well as petrographic studies clearly indicate that the compositional banding, defined by peak porphyroblastic phases was developed by segregation of partial melt (the leucosome layers) during $\mathrm{M}_{2}-\mathrm{D}_{2}$ event, and therefore has been designated as $\mathrm{S}_{2}$. Our structural study suggests that $\mathrm{S}_{1}$ foliation, defined by biotite-sillimanite-ilmenite-quartz, 
preserved in aluminous granulites, was developed during pre-peak $\mathrm{M}_{1}-\mathrm{D}_{1}$ event. The $\mathrm{S}_{1}$ foliation is thus only preserved in microscopic-scale and is completely absent in outcrop- and regional-scale. The subsequent high-temperature $\mathrm{M}_{2}-\mathrm{D}_{2}$ event completely obliterated the $\mathrm{S}_{1}$ foliation, except from few microdomains. Lack of $\mathrm{S}_{1}$ fabric in mesoscopicscale does not support the contention of Bhattacharya et al (1994) that the major NE-SW tectonic trends of the Eastern Ghats was produced during the first episode of folding. We have collated all the structural data of the present study in two 3D block diagrams representing the fold interference patterns and showing the relationship between different structural fabrics. These two interpretative block diagrams represent the mapped northeastern and south-western parts of the studied sector (figure 11a, b). Mesoscopic gneissic fabric, $\mathrm{S}_{2}$ is dominant in all lithological units and regionally parallel to $\mathrm{S}_{3}$ fabric (excepting the fold hinges). The transposed $\mathrm{S}_{2} / \mathrm{S}_{3}$ fabric can be correlated with the major tectonic trend of the EGB. Syn- $\mathrm{M}_{2}$ event would cause grain-scale deformation in porphyroblastic phases, but those signatures might be erased by static grain growth at high temperature near-peak metamorphic conditions that also accompanied melt/fluid. Probably most of the grain-scale signatures of deformation preserved in the rocks results from subsequent $\mathrm{M}_{3}-\mathrm{D}_{3}$ event.

Broadly E-W to WNW-ESE shortening is evident from $F_{3}$ fold patterns during $M_{3}-D_{3}$ event. Garnetiferous cordierite-bearing leucosomes occurring axial planar to $\mathrm{F}_{3}$ folds in aluminous granulites and along $\mathrm{D}_{3}$ boudinaged layers, developed during this event. Coarse-grained granitic materials are segregated/emplaced along transposed $\mathrm{S}_{2} / \mathrm{S}_{3}$ foliation in leptynite. Incipient charnockitization probably occurred during or after $\mathrm{M}_{3}-\mathrm{D}_{3}$ event in this rock as the charnockitized patches are superposed on the existing foliation of transposed $\mathrm{S}_{2} / \mathrm{S}_{3}$. Moreover, the charnockitized patches as well as non-charnokitic greasy metasomatic patches in the leptynitic (with/without garnet) host rock do not show any evidence of further deformation, at least in the outcrop-scale. Small-scale shear bands were developed parallel to $S_{3}$ foliation planes.

Anorthosite bodies occurring at the contacts of granulites record only one generation of weak foliation that shows warping. This foliation was probably developed during $\mathrm{M}_{3}-\mathrm{D}_{3}$ event when $\mathrm{S}_{2}$ gneissosity was transposed with $\mathrm{S}_{3}$ foliation in associated granulites. The last $\mathrm{D}_{4}$ event was weak enough to develop any penetrative foliation in the granulites except weak spaced-cleavages that developed in khondalite. The weak warping of the $\mathrm{S}_{3}$ foliation in anorthosite implies superposition of $\mathrm{D}_{4}$ event. Therefore, anorthosite plutonism seems
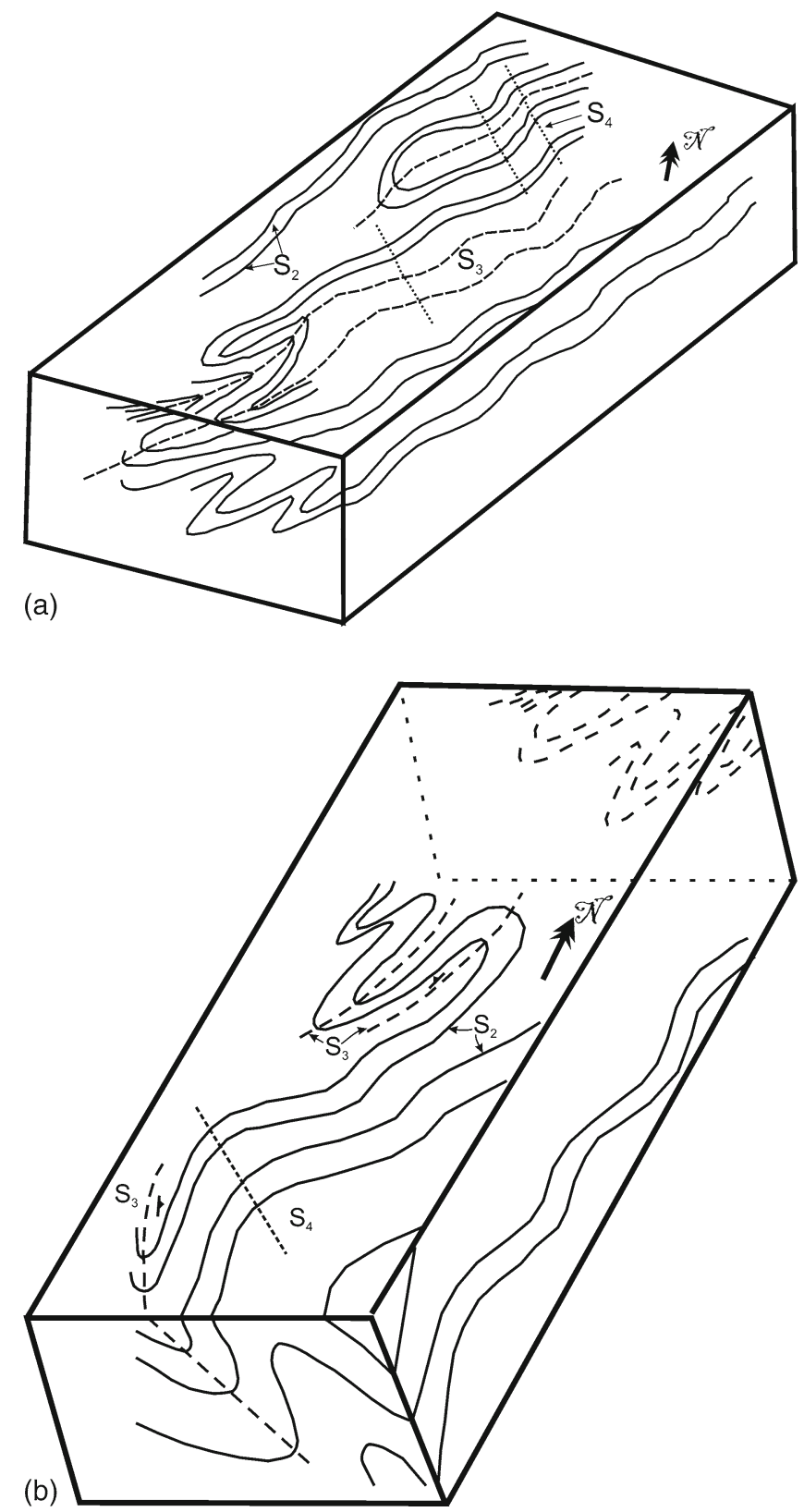

Figure 11. Schematic block diagrams of (a) north-eastern block and (b) south-western block of the studied area showing 3-D orientation of superposed planar geometry. The horizontal planes represent the mapped patterns of the respective blocks as in figure $3(\mathrm{a}, \mathrm{b})$.

to post-date $\mathrm{M}_{2}-\mathrm{D}_{2}$ stage and probably pre- to synchronous with $\mathrm{M}_{3}-\mathrm{D}_{3}$ event.

Our structural study points towards the presence of non-plane nature of folding developed due to interference of $\mathrm{F}_{3}$ and $\mathrm{F}_{4}$ during subsequent and last phase of $\mathrm{D}_{4}$ deformation. It is to be noted that Bhattacharya et al (1994) reported hookshaped non-plane interference pattern in khondalite of their $F_{1}$ and $F_{2}$ folds. However, careful observation from outcrop structures as well as from regional structural map suggests the interference of $\mathrm{F}_{3}$ and $\mathrm{F}_{4}$ are of non-cylindrical in addition to that. 
Thus in general non-plane non-cylindrical nature of interference pattern of $F_{3}$ and $F_{4}$ is suggested here, though it varies to plane non-cylindrical folding in few places. Broadly, N-S to NNE-SSW compression is evident during the last phase of folding $\left(\mathrm{F}_{4}\right)$ that produces a series of open upright superimposed folds on $\mathrm{F}_{3}$ gently plunging, recumbent to gently inclined and tight to isoclinals folds. Microscopically, brittle behaviour of quartz and feldspar grains suggests low-temperature deformational episode probably during $\mathrm{D}_{4}$ event.

Dobmeier and Simmat (2002) interpreted the structural evolution of the Chilka Lake area in terms of transpressional tectonics presumably resulting from oblique collision of Indian and east Antarctic Craton at ca. 690-660 Ma. The arguments put forward by these workers are:

- presence of sub-horizontal stretching lineation,

- a prominent lineament pattern observed from satellite imagery data,

- distribution of Mesozoic faults in the Mahanadi Offshore basin, and

- identification of two opposite sets of shear fabrics that implied reactivation of the erstwhile transpressional zone.

Transpression is a topic of intense research interest because of its large-scale implication in crustal dynamics (Sanderson and Marchini 1984; Robin and Cruden 1994; Jones et al 1997; Dewey et al 1998; Lardeaux et al 2001; Goscombe et al 2003, 2005). The fabric orientation, which is a key element of transpression, depends on factors such as angle of obliquity $(\alpha)$, intensity of finite strain (coaxial and/or noncoaxial) and kinematic partitioning. The angle of obliquity further controls the thermal regime and erosion rate of a transpressional system (Thompson et al 1997; Batt and Braun 1997). Moreover, the principal shortening surface (i.e., foliation) might show strike variation with the noncoaxial component of the strain, but dip remains vertical (cf. Druguet and Hutton 1998). Associated stretching lineation might switch from horizontal to vertical when $\alpha<20^{\circ}$ in case of monoclinic transpression (Sanderson and Marchini 1984). However, if there is a component of lateral (strike-parallel) stretch in the deformation zone, such lineation switch does not occur at all (Chattopadhyay and Khasdeo 2011). Thus, the relationship between stretching lineation and tectonic transport alone is not conclusive to distinguish imprints of transpression from that of compressional deformation. This implies that before relating regional lineament pattern to plate motion, a thorough appraisal of outcrop-based structural data on a regional-scale is needed to critically evaluate the proper tectonic build-up of crustal boundary zones. The idea of transpressional tectonics in Chilka Domain possibly emerged from the proposed collision of Indian and east Antarctic blocks. The interpretation of Dobmeier and Simmat (2002) regarding Chilka Lake granulites is significant. However, during the present study, we observed stretching lineation in localized shear zones and this is not a regionalscale fabric in the granulites. Structural features such as tight isoclinal folds, nappes, overfolds and thrusts that are common in transpression system (Tavarnelli et al 2004; Goscombe et al 2005) are not observed in Chilka Lake area. The regional lineament pattern in Dobmeier and Simmat's study matches with the regional foliation pattern of our study. The correlation of Mesozoic fault systems as reactivated transpressional boundaries appears to be extrapolation. As an alternative, the style of structural development in the Chilka Lake granulites can be explained from superposed fold geometries in response to compressional tectonics. It should be noted that the adjacent Angul Domain witnessed deformation pattern similar to Chilka Lake Domain, but no imprints of transpression is evoked from there (Sarkar et al 2007). Despite all these factors, it is difficult to discount regional transpression on the basis of absence of stretching lineation, etc., as the signatures of transpression are varied and the implied scale of transpressional tectonics (plate boundary scale) is larger than the regional- to mesoscopic/microscopic-scale structural analysis presented in this study.

Recently, Chatterjee et al (2010) identified N-S trending Eastern Indian Tectonic Zone (EITZ) encompassing highly deformed locales of Singhbhum and Chhotanagpur Cratons, north of EGB. Based on monazite ages, these authors put an age bracket of ca. 870-780 Ma for this event. Although geographically far apart, sheer coincidence of monazite ages from Chilka Lake area compels the authors to include the northern fringe of EGB within the EITZ. According to Chatterjee et al (2010), the ca. 870-780 Ma deformation and anatexis in EITZ was related to a distinct period of southward movement of India after its collision with east Antarctica during the Rodinia assembly (by ca. $900 \mathrm{Ma}$ ). This further implies that rifting related to Rodinia did not initiate before ca. $780 \mathrm{Ma}$. On the other hand, the ca. 715-655 Ma monazite age from the Chilka Lake anorthosite is interpreted to be related to the convergence and possible collision between the EGB-Rayner Block and Western Australian Craton (Chatterjee et al 2008).

Following all these interpretations, it appears that the Chilka Block, originally attached to EGB-Rayner Block during Rodinia assembly, witnessed compressional regime during its southward 
movement until its eventual collision with Western Australia. Available geochronological data indicate a distinct Neoproterozoic tectonothermal history for granulites of the Chilka Domain. In the present study, we identified four distinct metamorphic and deformation events $\left(\mathrm{D}_{1}-\mathrm{D}_{4}\right.$ events). Megascopic and microscopic data reveal that the petrological and structural imprints of these granulites are a product of these superposed events (two directions of compression being broadly $\mathrm{E}-\mathrm{W}$ for the earlier event and broadly $\mathrm{N}-\mathrm{S}$ for later event). As far as the structural geometry and fabric development patterns are concerned, we propose that Chilka Domain evolved through superposition of folds in overall compressional regimes at high angle, without significant transpression.

\section{Acknowledgements}

The authors acknowledge the financial grant from the Department of Science and Technology, Govt. of India through a research project (Grant no. ESS/16/251/2005). SK acknowledges the financial assistance to CAS, Department of Geological Sciences, Jadavpur University. Fieldwork assistance of Sayani Sarkar, Syamantak Chatterjee, Biplab Mahato, Souvik Sengupta and Partha Sarathi Das proved valuable in this work. Constructive and informative reviews of Dr S K Bhowmick and an anonymous reviewer helped to improve the quality of the paper.

\section{References}

Batt G E and Braun J 1997 On the thermomechanical evolution of compressional orogens; Geophys. J. Int. 128 364-382.

Bhadra S, Gupta S and Banerjee M 2004 Structural evolution across the Eastern Ghats Mobile Belt-Bastar Craton boundary, India: Hot over cold thrusting in an ancient collision zone; J. Struct. Geol. 26 233-245.

Bhattacharya S, Sen S K and Acharyya A 1993 Structural evidence supporting a remnant origin of patchy charnockites in the Chilka Lake area, India; Geol. Mag. 130 363-368.

Bhattacharya S, Sen S K and Acharyya A 1994 The structural setting of the Chilka Lake granulites-migmatitesanorthosite suite with emphasis on the time relation of charnockite; Precamb. Res. 66 393-409.

Bose S, Dunkley D, Dasgupta S, Das K and Arima M 2011a India-Antarctica-Australia-Laurentia connection in the Paleo-Mesoproterozoic revisited: Evidence from new zircon U-Pb SHRIMP and monazite chemical age data from the Eastern Ghats Belt, India; Bull. Geol. Soc. Am. 123 2031-2049.

Bose S, Das K, Chakraborty S and Miura H 2011b Petrology and geochemistry of metamorphosed basic intrusives from Chilka Lake granulites, Eastern Ghats Belt, India: Implications for Rodinia Breakup; In: Dyke Swarms (ed.) Srivastava R K (Berlin Heidelberg: Springer-Verlag), pp. 241-261.
Chatterjee N, Crowley J L, Mukherjee A and Das S 2008 Geochronology of the 983-Ma Chilka Lake Anorthosite, Eastern Ghats Belt, India: Implications for Pre-Gondwana tectonics; J. Geol. 116 105-118.

Chatterjee N, Banerjee M, Bhattacharya A and Maji A K 2010 Monazite chronology, metamorphism-anatexis and tectonic relevance of the mid-Neoproterozoic Eastern Indian Tectonic Zone; Precamb. Res. 179 99-120.

Chattopadhyay A and Khasdeo L 2011 Structural evolution of Gavilgarh-Tan Shear Zone, central India: A possible case of partitioned transpression during Mesoproterozoic oblique collision within Central Indian Tectonic Zone; Precamb. Res. 186 70-88.

Dasgupta S and Sengupta P 2003 Indo-Antarctic correlation: A perspective from the Eastern Ghats Granulite Belt, India; In: Proterozoic East Gondwana: Supercontinent Assembly and Beakup (eds.) Yoshida M, Windley B F and Dasgupta S, Geol. Soc. London Spec. Publ. 206 131-143.

Dewey J F, Holdsworth R E and Strachan R A 1998 Transpression and transtension zones; In: Continental Transpressional and Transtensional Tectonics (eds.) Dewey J F, Holdsworth R E and Strachan R A, Geol. Soc. London Spec. Publ. 135 1-14.

Dobmeier C 2006 Emplacement of Proterozoic massif-type anorthosite during regional shortening: Evidence from the Bolangir anorthosite complex (Eastern Ghats Province, India); Int. J. Earth Sci. 95 543-555.

Dobmeier C and Raith M 2000 On the origin of 'arrested' charnockitization in the Chilka Lake area, Eastern Ghats belt, India - a reappraisal; Geol. Mag. 137 27-37.

Dobmeier C J and Raith M M 2003 Crustal architecture and evolution of the Eastern Ghats Belt and adjacent regions of India; In: Proterozoic East Gondwana: Supercontinent Assembly and Beakup (eds) Yoshida M, Windley B F and Dasgupta S, Geol. Soc. London Spec. Publ. 206 $145-168$.

Dobmeier C and Simmat R 2002 Post-Grenvillian transpression in the Chilka Lake area, Eastern Ghats Belt -implications for the geological evolution of peninsular India; Precamb. Res. 113 243-268.

Druguet E and Hutton D H W 1998 Syntectonic anatexis and magmatism in a mid-crustal transpressional shear zone: An example from the Hercynian rocks of the eastern Pyrenees; J. Struct. Geol. 20 905-916.

Forbes C J, Betts P G, Weinberg $R$ and Buick I S 2007 A structural metamorphic study of the Broken Hill Block, NSW, Australia; J. Metamorph. Geol. 23 $745-770$.

Goscombe B 1992 High-grade reworking of central Australian granulites. Part 1. Structural evolution; Tectonophys. 204 361-399.

Goscombe B D, Hand M, Gray D and Mawby J 2003 The metamorphic architecture of a transpressional orogen: The Kaoko Belt, Namibia; J. Petrol. 44 676-711.

Goscombe B, Gray D and Hand M 2005 Extrusional tectonics in the core of a transpressional orogen; the Kaoko Belt, Namibia; J. Petrol. 46 1203-1241.

Gower R J W and Simpson C 1992 Phase boundary mobility in naturally deformed, high-grade quartzofeldspathic rocks: Evidence for diffusional creep; J. Struct. Geol. 14 301-313.

Jones R R, Holdsworth R E and Bailey W 1997 Lateral extrusion in transpression zones: The importance of boundary conditions; J. Struct. Geol. 19 1201-1217.

Karmakar S, Bose S, Das K and Dasgupta S 2009 Proterozoic Eastern Ghats Belt, India: A witness of multiple orogenies and its lineage with ancient supercontinents; J. Virtual Explorer, doi:10.3809/jv rtex.2009.00254. 
Kelly N M, Clarke G L, Carson C J and White R W 2000 Thrusting in the lower crust: Evidence from the Oygarden Islands, Kemp Land, East Antarctica; Geol. Mag. 137 219-234.

Krause O, Dobmeier C, Raith M M and Mezger K 2001 Age of emplacement of massif-type anorthosites in the Eastern Ghats Belt, India: Constraints from U-Pb zircon dating and structural studies; Precamb. Res. 109 25-38.

Lardeaux J M, Ledru P, Daniel I and Duchene S 2001 The Variscan French Massif Central - a new addition to the ultra-high pressure metamorphic 'club': Exhumation processes and geodynamic consequences; Tectonophys. 332 $143-167$.

Möller C, Andersson J, Lundqvist I and Hellström F 2007 Linking deformation, migmatite formation and zircon $\mathrm{U}-\mathrm{Pb}$ geochronology in polymetamorphic orthogneisses, Sveconorwegian Province, Sweden; J. Metamorph. Geol. 25 727-750.

Passchier C W and Trow R A J 2005 Microtectonics, Springer Verlag, pp. 366.

Raith M M, Dobmeier C and Mouri H 2007 Origin and evolution of $\mathrm{Fe}-\mathrm{Al}$ granulites in the thermal aureole of the Chilka Lake anorthosite, Eastern Ghats Province, India; Proc. Geol. Assoc. 118 87-100.

Ramakrishnan M, Nanda J K and Augustine P F 1998 Geological evolution of the Proterozoic Eastern Ghats Mobile Belt; Geol. Surv. India Spec. Publ. 44 1-21.

Rickers K, Mezger K and Raith M M 2001 Evolution of the continental crust in the Proterozoic Eastern Ghats Belt, and new constraints for Rodinia reconstruction: Implications from $\mathrm{Sm}-\mathrm{Nd}, \mathrm{Rb}-\mathrm{Sr}$ and $\mathrm{Pb}-\mathrm{Pb}$ isotopes; Precamb. Res. 112 183-212.

Robin P Y and Cruden A R 1994 Strain and vorticity patterns in ideally ductile transpression zones; J. Struct. Geol. 16 447-466.
Rogers J J W and Santosh M 2002 Configuration of Columbia, a Mesoproterozoic Supercontinent; Gondwana Res. 5 5-22.

Rogers J J W and Santosh M 2009 Tectonics and surface effects of the supercontinent Columbia; Gondwana Res. 15 373-380.

Saha L, Bhowmik S K, Fukuoka M and Dasgupta S 2008 Contrasting episodes of regional granulite-facies metamorphism in enclaves and host gneisses from the AravalliDelhi mobile belt, NW India; J. Petrol. 49 107-128.

Sanderson D J and Marchini W R D 1984 Transpression; J. Struct. Geol. 6 449-458.

Sarkar M, Gupta S and Panigrahi M 2007 Disentangling tectonic cycles along a multiply deformed terrane margin: Structural and metamorphic evidence for mid-crustal reworking of the Angul granulite complex, Eastern Ghats Belt, India; J. Struct. Geol. 29 802-818.

Sen S K, Bhattacharya S and Acharya A 1995 A multistage pressure-temperature record in the Chilka Lake granulites: The epitome of the metamorphic evolution of Eastern Ghats, India? J. Metamorph. Geol. 14 287-298.

Sengupta P, Dasgupta S, Dutta N and Raith M M 2008 Petrology across a calc-silicate-anorthosite interface from the Chilka Lake Complex. Orissa: Implications for Neopoterozoic crustal evolution of the Eastern Ghats Belt; Precamb. Res. 162 40-58.

Tavarnelli E, Holdsworth R E, Clegg P, Jones R R and McCaffrey K J W 2004 The anatomy and evolution of a transpressional imbricate zone, Southern Uplands, Scotland; J. Struct. Geol. 26 1341-1360.

Thompson A B, Schulmann K and Jezek J 1997 Extrusion tectonics and elevation of lower crustal metamorphic rocks in convergent orogens; Geology 25 491-494.

Zhao G, Sun M, Wilde S A and Li S 2004 A PaleoMesoproterozoic supercontinent: Assembly, growth and breakup; Earth Sci. Rev. 67 91-123. 